\title{
THE CORRELATION OF KNOWLEDGE AND SELF-EFFICATION IN PREVENTING THE SPREAD OF PULMONARY TUBERCULOSIS
}

\author{
Bisepta Prayogi \\ STIKes Patria Husada Blitar \\ email: bisepta87@gmail.com
}

\begin{abstract}
The World Health Organization (WHO) has stated that the current situation of Tuberculosis (TB) worldwide is getting worse. Based on the survey conducted by the Ministry of Health of the Republic of Indonesia (2011) on the prevalence of TB in 2009, knowledge shows that $76 \%$ of families have heard about TB and $85 \%$ know that TB can be cured, but only $26 \%$ can mention two signs and symptoms main TB. The mode of transmission of TB is understood by $51 \%$ of families and only $19 \%$ know that TB drugs are available for free. The purpose of this research was to know the correlation of knowledge and selfefficacy about prevention of transmission in lung tuberculosis patients. Methods: The research design used correlational with the cross-sectional approach. The population was lung TB patients in the working area of Ponggok Puskesmas. The sampling technique used purposive sampling with the sample of 20 respondents. The data collected then processed and analyzed with spearman-rho statistic test with a significance value of 0.05 . Results: The results showed significance value $p=0,001(p<0,05)$. Thus there was a corelation of knowledge and self-efficacy about prevention of transmission of pulmonary tuberculosis.Discussion: Knowledge was one factor that plays a role in the formation of self-efficacy in patients with pulmonary tuberculosis.
\end{abstract}

Keywords: knowledge, self-efficacy, pulmonary TB patients.

The World Health Organization (WHO) has stated that the current situation of Tuberculosis (TB) worldwide is getting worse, this is because the number of TB cases continues to increase and the rate of recovery is low. WHO has launched TB as a global emergency, primarily because of the epidemic of Human Immunodeficiency Virus (HIV ( AIDS) and the case of MultiDrug Resistance (MDR)(Kemenkes RI, 2014).

According to the Global Tuberculosis Report released by WHO in 2016, the world's new TB case by 2015 was $10,400,000$ cases, of which 480,000 new TB cases were new cases of MDR$\mathrm{TB}$, with the deaths of $1,400,000$ people, of that number 400,000 died of TB-HIV.Countries with the highest TB cases of 2015 are India, Indonesia, China, Nigeria, Pakistan and South Africa.Thus Indonesia ranks 2nd largest TB sufferers globally (WHO, 2016).
Tuberculosis is also included in the 3 rd SDGs (Sustainable Development Goals) program, which is to ensure a healthy life and promote well-being for all people of all ages with a targeted end to the Tuberculosis epidemic by reducing the death rate from tuberculosis by $90 \%$ and reducing the incidence rate TB by $80 \%$ by 2030 (Amrin, 2016).

Based on data from the section on Disease Eradication (P2) in Dinas Kesehatan Kabupaten Blitar, in 2015 new cases of Tuberculosis patients as many as 632 people and patients who undergoing re-treatment as many as 13 people, so that total TB patient who received OAT treatment of 645 people. While in 2016 in Blitar district, the number of new TB patient findings as many as 669 people and who undergoing re-treatment as many as 22 people so that the total number of TB patients in Blitar district in 2016 as many as 691 people. Based on these 
data there is an increase in the number of TB patients by 3.3\% (Dinkes Blitar, 2016)

Based on data from Integrated Tuberculosis Information System (ITIS), In the work area of Puskesmas Ponggok Kabupaten Blitar, the number of TB patients in 2015 was 34 people and in 2016 as many as 33 people. From the results of contact tracing conducted by the researchers obtained data that almost $50 \%$ of TB patients who undergo treatment at Ponggok Puskesmas in 2015 until 2016 ha a history of contact with patients withthe previous TB.

Based on the survey conducted by the Ministry of Health of the Republic of Indonesia (2011) on the prevalence of TB in 2009, knowledge shows that $76 \%$ of families have heard about TB and $85 \%$ know that TB can be cured, but only $26 \%$ can mention two signs and symptoms main TB. The mode of transmission of TB is understood by $51 \%$ of families and only $19 \%$ know that TB drugs are available for free. The results of preliminary studies at Puskesmas Ponggok stated that 3 of 5 Pulmonary TB sufferers have sufficient knowledge and confidence about prevention of transmission of pulmonary TB disease. The purpose of this research is to know the relationship between knowledge and self-efficacy about prevention of transmission in lung tuberculosis patients.

\section{RESEARCH METHODS}

The research design used was correlational with cross-sectional approach. The population is lung TB patients in the working area of Ponggok Puskesmas. Sampling technique using purposive sampling with asample of 20 respondents.

The independent variable is knowledge, while the dependent variable is self-efficacy. Instruments used: 1) Questionnaires to collect demographic data include gender of respondent, age, education, occupation, religion, income, 2) Questionnaire to measure knowledge and self-efficacy. The data has been collected and then processed and analyzed using spearman-rho statistic test with adegree of significance $p=0,05$.

\section{RESULTS}

Results of Knowledge of Pulmonary TB Responders at Puskesmas Ponggok Blitar Regency May 2017
Table1 Results of Knowledge of Pulmonary TB Responders at Puskesmas Ponggok Blitar Regency May 2017

\begin{tabular}{lcc}
\hline Knowledge & f & \% \\
\hline Good & 13 & 65 \\
Enough & 7 & 35 \\
\hline Total & $\mathbf{2 0}$ & $\mathbf{1 0 0}$ \\
\hline
\end{tabular}

Table1 shows that most respondents have good knowledge of 13 respondents or $65 \%$. Only a small percentage of respondents who have sufficient knowledge as much as 7 respondents or by $35 \%$.

Results of self-efficacy of Pulmonary TB Responders at Puskesmas Ponggok Blitar Regency May 2017

Tabel 2 Results of self-efficacy of Pulmonary TB Responders at Puskesmas Ponggok Blitar Regency May 2017

\begin{tabular}{lcc}
\hline Self-efficacy & f & \% \\
\hline Good & 12 & 60 \\
Enough & 8 & 40 \\
\hline Total & $\mathbf{2 0}$ & $\mathbf{1 0 0}$ \\
\hline
\end{tabular}

From Table 2 shows most respondents have good self-efficacy as much as 12 respondents or by $60 \%$. Only a small percentage of respondents who have Self Self-efficacy as much as 8 respondents or by $40 \%$.

Results of correlation Between Knowledge and Self-Efficacy of Pulmonary TB Responders at Puskesmas Ponggok Blitar District May 2017

Table 3 Results of correlation Between Knowledge and Self-Efficacy of Pulmonary TB Responders at Puskesmas Ponggok Blitar District May 2017

\begin{tabular}{lccc}
\hline \multirow{2}{*}{ Knowledge } & \multicolumn{2}{c}{ Self-efficacy } & \multirow{2}{*}{ total } \\
\cline { 2 - 3 } & Good & Enough & \\
\hline Good & 11 & 2 & $\mathbf{1 3}$ \\
Enough & 1 & 6 & $\mathbf{7}$ \\
\hline Total & $\mathbf{1 2}$ & $\mathbf{8}$ & $\mathbf{2 0}$ \\
\hline
\end{tabular}

Spearman's Rho $p=0,001$ 
From Table 3 shows the significance value $\mathrm{p}=$ $0.001(\mathrm{p}<0.05)$. Thus there is a relationship between knowledge and self-efficacy about prevention of transmission of pulmonary tuberculosis. From the analysis results obtained the value of close relationship 0.685 which means there is a strong relationship. The conclusion of the analysis is that there is a strong relationship between knowledge and self-efficacy, where the better the knowledge, the better the self-efficacy of the lung TB patient.

\section{DISCUSSION}

The correlation Between Knowledge and SelfEfficacy of Pulmonary TB Responders at Puskesmas Ponggok Blitar District May 2017

Based on the results of cross-tabulation between knowledge and self-efficacy indicates that the average patient of Pulmonary TB has good knowledge and self-efficacy, it is characterized by the sufferers of Pulmonary TB have a strong belief in its ability to exert all efforts in order not to transmit the disease and can heal completely. The respondent hopes his illness is not transmitted to others, especially to his family. This encourages respondents to comply with all care programs. Respondents always adhere to the advice given by health workers, especially on prevention of pulmonary TB transmission. Various attempts were made by respondents to prevent transmission, such as using a mask when talking to others, keeping the environment clean, and throwing sputum into a special container. Other results seen there is 1 respondent who is knowledgeable enough but efficacy himself good, this is probably due to patients always get attention from family to keep the behavior so that other family members are not infected.

This research shows that knowledge is one of the factors of self-efficacy formation. Knowledge can be the basis for the individual to determine his attitude and behavior. Knowledge of one's own knowledge is influenced by several factors such as age, education, job / experience, information / mass media, socio-cultural and economic, environment (Mubarak, 2007). Providing good information on prevention of TB transmission by health personnel is very important to be done so that knowledge about prevention of transmission of respondents to be increased. The results of this study in accordance with research conducted by Prabandari (2014) that the better the level of one's knowledge the better the motivation of a person is undergoing atreatment program.

Spearman rho test results obtained $\mathrm{p}$-value $=$ 0.001 with $\alpha=0.05$. This means that there is a meaningful relationship between knowledge and self-efficacy of pulmonary TB patients about prevention of transmission of pulmonary TB disease. Spearman correlation value 0.685 shows the direction of correlation is positive and have a strong correlation. Based on the results of this analysis indicates that knowledge is one factor that plays a role in the formation of self efficacy in patients with pulmonary tuberculosis in PKM Ponggok Blitar Regency, whereas other than knowledge there are other factors that can affect the formation of self efficacy that is the experience of individuals, in this study there are three respondents which are classified as an old patient, the intended old patient is a patient with a case of relapse, this can affect the beliefs of patients with pulmonary TB. Pulmonary TB sufferers who responded stated that they believed they could prevent transmission of pulmonary tuberculosis because they had been frequently informed about prevention of transmission given by health workers.

\section{CONCLUSIONS AND SUGGESTIONS}

\section{Conclusions}

Based on this research, it can be concluded that there is a significant relationship between knowledge with self-efficacy about prevention of transmission of pulmonary TB disease at Puskesmas Ponggok Blitar regency.

\section{Suggestions}

For nurses can be used as a study to always provide health education on prevention of transmission of pulmonary TB disease, so that the self-efficacy of Pulmonary TB patients increases. Patients with pulmonary tuberculosis are expected to maintain good self-efficacy, so they can heal optimally and not spread to others. For families in the hope always give attention and support to family members who suffer from pulmonary tuberculosis.

\section{REFERENCE}

Amrin, madolan. 2013. Goals (Tujuan) Dan target SDGs Kesehatan, Online. www.mitrakesmas.com. Diakses tanggal 1 Maret 2017. 
Depkes RI. 2009. Sistem Kesehatan Nasional. Jakarta: Departemen Kesehatan Republik Indonesia.

Kemenkes RI. 2014. Pedoman Nasional Pengendalian Tuberculosis. Jakarta: Dirjen Pengendalian Penyakit Dan Penyehatan Lingkungan.

Mubarak, Wahid Iqbal dkk. 2007. Promosi Kesehatan Sebuah Metode Pengantar Proses Belajar Mengajar Dalam Pendidikan. Yogyakarta: Graha Ilmu
Prabandari, I. 2014. Hubungan tingkat pengetahuan dengan motivasi untuk memeriksakan diri pasien hipertensi pada Lanjut Usia di Puskesmas Kerjo Karanganyar. Jurnal Keperawatan Univ. Muhammadiyah Surakarta April 2014.

WHO. 2016. Global Tuberculosis Report, online. www.who.int. Diakses Tanggal 10 Maret 2017. 